\title{
Multimedia i edukacja 2.18
}

\author{
Multimedia and education 2.18
}

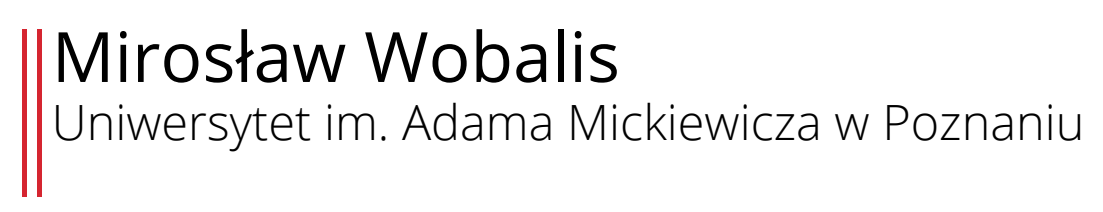

\begin{abstract}
In the article the author discusses the main phenomena related to technologies that are representative for the second decade of the 21 st century, which have the strongest impact on recipients (especially on children and teenagers), and thus on education. The article describes the relationship between technologies and teaching with a special focus put on the positive and negative impact on education. The author of the article also presents the main principles of the operation of digital technologies and related with them new media (or so-called 'new new media'). Furthermore, the article also presents data of the level of computerization of Poland and compares them with the level of computerization of Polish schools. The author presents the current core curriculum of computer science and the Polish language in the context of their references to digital technologies and digital communication skills.
\end{abstract}

Key words: multimedia, new media, education, core curriculum, digital technologies

Streszczenie: W artykule autor omawia główne zjawiska związane z technologiami będące reprezentatywnymi dla drugiej dekady XXI wieku, które najsilniej oddziałują na odbiorców (szczególnie na dzieci i młodzież), a tym samym na edukację. Opisuje relacje między technologiami a nauczaniem ze szczególnym skupieniem się na pozytywnym oraz negatywnym ich wpływie na kształcenie. Przedstawia główne zasady działania technologii cyfrowych, a także powiązanych z nimi nowych mediów (i dalej tzw. nowych nowych mediów). W dalszej kolejności przywołuje dane dotyczące poziomu komputeryzacji Polski i zestawia je z poziomem komputeryzacji polskich szkół. Prezentuje aktualne podstawy programowe informatyki oraz języka polskiego w kontekście ich nawiązań do technologii cyfrowych i cyfrowych kompetencji komunikacyjnych.

Słowa kluczowe: multimedia, nowe media, edukacja, podstawa programowa, technologie cyfrowe 


\section{Wprowadzenie}

Zanim przejdę do właściwej części artykułu, winny jestem drobne wyjaśnienie dotyczące zarówno jego tytułu, jak i podjętej problematyki. W czerwcu 1997 roku, tuż po obronie pracy magisterskiej poświęconej legendom literackim Witkacego, Profesor Seweryna Wysłouch (promotorka tej pracy) przedstawiła mnie Profesor Bożenie Chrząstowskiej. Moje opowieści dotyczące realizowanych przeze mnie ówcześnie pozauczelnianych projektów związanych z technologiami komputerowymi, multimediami, a zwłaszcza ich związkami z edukacją, wywołały zainteresowanie autorki Lektury i poetyki. Poproszony zostałem o napisanie do „Polonistyki” artykułu poświęconego multimediom i edukacji. Dla świeżo upieczonego polonisty prośba redaktor naczelnej tak znanego pisma była niczym zrządzenie losu. Powstały 21 lat temu artykuł Multimedia i edukacja koncentrował się głównie na praktycznych sposobach wykorzystania technologii komputerowych i multimediów w kształceniu polonistycznym. Ku mojemu wielkiemu zaskoczeniu tekst otwierał 3. numer „Polonistyki” z roku 1998, znalazł też odbiorców, o czym świadczyły znajdowane w różnych publikacjach odwołania i przypisy (Wobalis 1998). Tak zaczęła się wieloletnia znajomość z Bożeną Chrząstowską, późniejszą promotorką mojej rozprawy doktorskiej.

Wspomnienie to zainspirowało mnie dwadzieścia lat później do przyjrzenia się tym samym zagadnieniom. Dla edukacji to okres dość krótki, dla technologii bardzo długi. W tym czasie zmieniło się nie tylko samo otoczenie technologiczne, ale także sposoby komunikowania się. Świat stał się bardziej wirtualny i cyfrowy, ingerując coraz silniej w rzeczywistość realną i zmysłową. Przemiany te nie pozostały bez wpływu na edukację. Pozwoliłem sobie więc sięgnąć ponownie do tematu podjętego przed laty, dodając drobny dopisek wskazujący zarówno na datę jego napisania, ale również odwołujący się do samej technologii cyfrowej, a właściwie sposobu nazywania kolejnych wersji programów komputerowych.

\section{Od technologii cyfrowych do nowych nowych mediów}

W roku 2018 technologie cyfrowe rozumiane jako narzędzia komputerowe (zarówno sprzętowe, jak i programistyczne) są powszechne. Narzędzia te są tak wszechobecne, że statystycznie na jednego mieszkańca krajów rozwiniętych (Polska weszła do tego elitarnego grona 25 państw świata dopiero w roku 2017) przypada więcej niż jedno urządzenie cyfrowe. Te zaś najczęściej podłączone są do globalnej sieci Internet, która przez minione ćwierćwiecze stała się już nie tylko bazą informacji, ale także przestrzenią codziennego funkcjonowania dla miliardów użytkowników (mówimy o miliardach użytkowników dziennie). Technologie informatyczne i nowe media stały się narzędziem handlowym (sklepy internetowe generują dzisiaj większy obrót niż sklepy tradycyjne), usługowym (od pośrednictwa sprzedaży przez wszelkiego typu doradztwo, bankowość, po medycynę), 
administracyjnym (w ramach administracji publicznej i lokalnej), obywatelskim (jako platforma wymiany informacji i zrzeszania się), edukacyjnym (w ramach nauczania zdalnego i stacjonarnego), zawodowym (organizacja pracy stacjonarnej i praca zdalna), ale także jest narzędziem inwigilacji, propagandy i rozrywki ${ }^{1}$.

Samo określenie technologie cyfrowe odnosi się do sposobu ich funkcjonowania polegającego na tym, że podstawowym budulcem każdego przekazu cyfrowego jest bit jako najmniejszy znacznik informacji, który nie dość, że nie ma formy fizycznej, to w dodatku jedynie określa stan napięcia elektrycznego w zamkniętym układzie elektronicznym. Od lat 50. XX wieku, za Claudem Shannonem, możemy określać sposób wirtualnego „łączenia” pojedynczych bitów w większe porcje informacji, tworzyć narzędzia przekazywania ich przez różnorodne łącza, a w końcu przetwarzania ich w struktury uproszczone algorytmicznie (skompresowane) zgodnie z zasadami entropii informacyjnej. Niezależnie jednak od całego sztafażu technologicznego komunikacji cyfrowej, tym, co konstytuuje istnienie cyfrowego bytu, jest wyłącznie wymieniony wyżej stan napięcia elektrycznego: albo owo napięcie jest (1), albo go nie ma (0). Każda bardziej złożona forma informacji w formie obrazu, dźwięku, tekstu, filmu, gry komputerowej zawiera w sobie ten sam składnik - 0 lub $1 \mathrm{w}$ formie zwielokrotnionej przez odpowiedni dla danej formy kod. Bit postrzegany metaforycznie jest więc dla świata cyfrowego tym, czym dla świata fizycznego jest najprostsza cząsteczka. Różnica polega jednak na tym, że pierwsze jest wyłącznie wirtualnym stanem, zaś drugie zawsze materialnym konstruktem złożonym $\mathrm{z}$ dwóch lub więcej atomów.

Uwaga powyższa, dotycząca fizyczności bytu materialnego, wydaje się konieczna dla zrozumienia najistotniejszych ograniczeń cyfrowego środowiska, w którym realizowane są współczesne cyfrowe praktyki komunikacyjne (także twórcze i edukacyjne). Środowisko to jest bowiem zawsze: a) wirtualne - „istnieje” w przestrzeni urządzenia elektronicznego i tylko za pośrednictwem takiego urządzenie jest dostępne, b) technologiczne - „istnieje" wyłącznie dzięki urządzeniom korzystającym z infrastruktury opartej na technologii elektrycznej, c) umowne - reprezentacja zmysłowa bytu wirtualnego postrzegana przez człowieka jest zawsze zależna od narzędzia transmitującego, a więc dla różnych odbiorców może mieć różną formę, d) zamknięte - przekaz zawsze ograniczony jest możliwościami urządzeń oraz założeniami zapisanymi kodem algorytmu. Każda komunikacyjna forma działania w takim ograniczonym środowisku posiadać będzie dwie

\footnotetext{
${ }^{1}$ Tzw. przemysł kreatywny obejmuje produkcję szerokiej gamy usług medialnych od przekazywania informacji, tworzenia i dystrybucji filmów i muzyki, poprzez komunikację społecznościową (tzw. media społecznościowe), aż po gry komputerowe, które są dzisiaj codzienną rozrywką setek milionów ludzi. Co istotne, przemysł kreatywny ściśle przenika się z przemysłem informatycznym (kapitałowo i organizacyjnie), sprawiając, że oba obszary nawzajem się stymulują na zasadzie synergii. Tak zorganizowany medialny i technologiczny konglomerat przekazów, wszelakich narzędzi, usług i urządzeń cyfrowych w istotny sposób tworzy społeczny wizerunek samych technologii cyfrowych i nowych mediów. Zob. Filiciak M., 2013, Media, wersja beta. Film i telewizja w czasach gier komputerowych i Internetu, Gdańsk.
} 
zasadnicze wady: jedna wynika z konieczności pełnego zanurzenia się w jednym tylko środowisku (nie da się połączyć bitu i cząsteczki i nie da się jednocześnie być analogowym i cyfrowym), druga zaś ułomność wynikać będzie z konieczności stosowania specyficznych narzędzi oddziaływania w danej przestrzeni².

Media komunikacyjne niezmiennie sytuowane są w roli pośrednika między nadawcą komunikatu a jego odbiorcą (lub odbiorcami w przypadku mediów masowych), choć i tu w ciągu ostatnich 20 lat odkryć można kilka zaskakujących ścieżek rozwoju (Goban-Klas 1998). Można też dostrzec, jak rozbudowuje się terminologia opisująca media, a zwłaszcza nowe media cyfrowe, oraz proces ich konwergencji (Manovich 2012, Jenkins 2007, Kellner 2009)3. Realizuje się to w procesie wzajemnego stymulowania się coraz liczniejszych i coraz bardziej rozproszonych źródeł, nośników, technologii, ośrodków informacji itd. Przenikające się i nakładające się na siebie obrazy kulturowe (patrz: model informacyjno-komunikacyjny mozaiki kulturowej Abrahama Molesa ${ }^{4}$ ), działając poprzez media, tworzą i przekształcają kulturę. Nowa kultura medialna reorganizuje istniejący porządek komunikacyjno-medialny $\mathrm{w}$ zglobalizowany cyfrowy porządek nowomedialny. Ten nowy „społeczno-kulturalny obraz świata” (określenie Molesa) przekształca kulturę w kierunku dzisiaj jeszcze nieznanym. O ile w dawnych wiekach proces ten odbywał się przez setki lat, a technologie informacyjne jak pismo, kodeks czy druk stopniowo (choć trwale) modyfikowały kulturę, to współcześnie procesy te odbywają się znacznie szybciej. Co więcej, od czasu powstania i dynamicznego rozwoju mediów społecznościowych, takich jak Facebook, YouTube, Twitter, Instagram itp. (nazywanych przez Paula Levinsona nowymi nowymi mediami ${ }^{5}$ ), cyfrowa kultura medialna ulega rozproszeniu na liczne ośrodki lokalne, enklawy, wyspy odrębności tworzące własne prawdy (lub postprawdy) i kultury (lub subkultury). Podobne zjawisko rozproszenia obserwujemy też w nauce, edukacji, sztuce, rozrywce, informacji, a nawet w sporcie.

Złożoność komunikacyjna początku XXI wieku, wpływająca w sposób bezpośredni na postawy kreatywne cyfrowych komunikatorów, związana jest ze współistnieniem w życiu codziennym dwóch podstawowych dzisiaj systemów komunikacyjnych. Jednym z nich jest system analogowy, związany z praktykami i narzędziami komunikacyjnymi wynikającymi z pierwotnego, werbalnego oraz niewerbalnego, porządku wzrokowo-słuchowego

\footnotetext{
${ }^{2}$ Nie da się przenieść wirtualnej rzeczywistości cyfrowej do świata materialnego bez użycia technologii cyfrowych, tak jak nie da się użyć tradycyjnego pędzla do namalowania cyfrowego obrazu.

3 „Jako konwergencję rozumiem przepływ treści pomiędzy różnymi platformami medialnymi, współpracę różnych przemysłów medialnych oraz migracyjne zachowania odbiorców mediów, którzy dotrą niemal wszędzie, poszukując takiej rozrywki, na jaką mają ochotę. Konwergencja to pojęcie opisujące zmiany technologiczne, przemysłowe, kulturowe i społeczne. (...) Zamiast mówić o pełniących oddzielne role producentach i konsumentach mediów, możemy dziś raczej postrzegać jednych i drugich jako uczestników wchodzących ze sobą w interakcje" (Jenkins 2007, 9).

${ }_{4}$ Moles A., 1967, Sociodynamique de la culture, Paris. Zob. Filiciak M., 2003, Homo communicans. Wprowadzenie do teorii masowego komunikowania, Lublin, s. 91-94.

${ }^{5}$ Levinson P., 2010, Nowe nowe media, Kraków.
} 
realizowanego interpersonalnie i pośrednio z wykorzystaniem mediów analogowych. Drugi to system cyfrowy, związany wyłącznie z praktykami i narzędziami wywodzącymi się ze świata technologii informatycznych (cyfrowych). Oba porządki odmiennie regulują i organizują sposoby oraz formy komunikowania się, zaś różnice są tak zasadnicze, że jedyną de facto dominującą dzisiaj formułą komunikowania się ludzi jest komunikacja hybrydowa polegająca na nieustannym przechodzeniu/przełączaniu się komunikatorów pomiędzy obydwoma systemami ${ }^{6}$. Przykładem tej specyficznej „schizofrenii komunikacyjnej” jest jednoczesne współistnienie osób jako bytów fizycznych w świecie rzeczywistym oraz bytu/bytów wirtualnych w świecie cyfrowym.

Nie powinno więc dziwić, że tak powszechne dzisiaj technologie cyfrowe pojawiają się w szkole jako narzędzia wspierające nauczanie. Szczególnie jednak istotne wydaje się, by stanowiły istotny element programów kształcenia dotyczący prezentowania i wyjaśniania najważniejszych zjawisk komunikacyjnych i kulturowych XXI wieku - w tym także (a może szczególnie) w zakresie nauczania języka polskiego.

\section{„Polska cyfrowa”}

Polacy uważają się za naród rozwinięty cyfrowo, ale twarde dane przekonanie to weryfikują. Ponad 70\% populacji korzysta z Internetu (średni wskaźnik korzystania z Internetu dla UE wynosi 79\%), jednak jedynie 44\% Polaków może pochwalić się podstawowymi umiejętnościami ${ }^{7}$ poruszania się po cyfrowym świecie (średni wskaźnik dla UE wynosi 56\%). Takie dane zaprezentowali w roku 2017 eksperci Komisji Europejskiej (Jan Arkady Malinowski) i Deloitte (Piotr Arak) podczas sesji Rozwój cyfrowy i umiejętności cyfrowe w Unii Europejskiej i w Polsce 2017. Z wyników innych badań wynika, iż współczynnik DESI 2017 (The Digital Economy and Society Index) dla Polski w porównaniu z innymi krajami UE jest dość niski, Polska zajmuje pod tym względem 23. miejsce w UE (na 28 państw) ${ }^{8}$. Rok temu Polacy byli na miejscu 24., w roku 2014 było to miejsce 22. Pierwsze miejsce w tym rankingu zajmuje Dania, druga jest Finlandia, trzecia Szwecja.

W roku 2017 większość Polaków dysponowała mobilną łącznością szerokopasmową (94 na 100 osób) jednak tylko 57\% gospodarstw domowych posiadało stacjonarne szerokopasmowe połączenie z Internetem

\footnotetext{
${ }^{6}$ Zob. Wobalis M., 2008, Hybrydowy podręcznik multimedialny narzędziem czytania tekstów kultury, w: Teksty kultury w szkole, Myrdzik B., Tymiakin L. (red.), Lublin, s. 377-386; Zacher L.W., 2012, Refleksje o ideologii cyfrowego świata, w: Nasza cyfrowa przyszłość. Nadzieje - ryzyka - znaki zapytania, Komitet Prognoz „Polska 2000 Plus” przy Prezydium PAN, Warszawa, s. 115; Puppel S., 2012, The human communication orders and the principle of natural language sustainability, „Oikeios Logos”, nr 9, s. 9-10.

7 Do podstawowych umiejętności cyfrowych zaliczono między innymi: obsługę poczty elektronicznej, komunikatora tekstowego, znajomość zabezpieczeń, wiedzę o funkcjach i znaczeniu haseł i loginów, obsługę narzędzi biurowych, wykonywanie kopii zapasowych plików i umiejętność weryfikacji informacji znalezionych w sieci.

8 Szczegółowe wskaźniki DESI 2017 dla Polski: [Online:] https://ec.europa.eu/newsroom/document.cfm?doc id=43033. Dostęp: 03.10.2018.
} 
(26. miejsce w UE) zaś Polska sklasyfikowana została na ostatniej pozycji w rankingu zasięgu stacjonarnej łączności szerokopasmowej ${ }^{9}$. Analizując inne dane (komputeryzacja przedsiębiorstw, urzędów, bibliotek), można stwierdzić, że pod względem dostępu społeczeństwa do narzędzi i usług cyfrowych Polska nie odstaje od średniej europejskiej. Nieco inaczej przedstawia się sytuacja szkół. O ile komputery (jako samodzielne urządzenia) znajdziemy w praktycznie każdej szkole, to nierozwiązywalnym od lat problemem pozostaje zagwarantowanie placówkom oświatowym dostępu do Internetu o wysokiej prędkości gwarantującego bezproblemową pracę grupową w sieci - w tym korzystanie z najlepszej jakości multimediów tak istotnych w obrazowaniu zjawisk czy procesów. Według statystyk Ministerstwa Edukacji Narodowej tylko 3 tys. szkół korzysta z szybkiego Internetu powyżej 100 Mbps, w 40\% nie przekracza 10 Mbps, a 1/4 polskich uczniów nie ma w ogóle możliwości korzystania z globalnej sieci na zajęciach ${ }^{10}$.

Odnosząc się do mojego tekstu opublikowanego w "Polonistyce” w 1998 r., Seweryna Wysłouch zadała wówczas następujące pytanie:

Czy tak właśnie będzie wyglądać nasza przyszłość? Multimedialny podręcznik języka polskiego? (Wysłouch 1998, 131).

Dzisiaj, po upływie 21 lat, mogę jednoznacznie odpowiedzieć, że nic takiego nie nastąpiło. Podręczniki multimedialne $\mathrm{w}$ formule $\mathrm{z}$ lat 90 . XX wieku, a więc w postaci nośników CD-ROM (lub DVD-ROM), nie pojawiły się $\mathrm{w}$ szkole, zaś edukacyjne programy multimedialne sprzedawane niezależnie lub dołączane do podręczników z czasem również zaczęły znikać z rynku. Powód był bardzo prosty - wszystkie pomoce dydaktyczne zostały przeniesione do Internetu i tam są dzisiaj dostępne (zniknęła zatem potrzeba korzystania z nośników CD-ROM). Ma to swoje wielkie zalety, ale także istotne wady. W grupie zalet należy umieścić łatwość dostępu (można z tych samych treści korzystać w szkole, w domu, a nawet na urządzeniach mobilnych). Innym walorem jest to, że w dużej części korzystanie z tego typu narzędzi sieciowych powiązane jest z koniecznością logowania się do specjalistycznych serwisów internetowych (często tworzonych przez znane wydawnictwa edukacyjne), co gwarantuje łatwe personalizowanie serwisów (np. grupowanie treści), dodawanie kolejnych materiałów czy w końcu kontakt z innymi użytkownikami. Ważna jest też możliwość wspólnej pracy w sieci nauczyciela z uczniami lub/i rodzicami z wykorzystaniem specjalistycznych aplikacji lub serwisów korzystających z Internetu. Ułatwia to nie tylko kontakt z uczniami i rodzicami (np. przez powiadamianie ich o istotnych szkolnych sprawach przez e-mail czy sms), ale także wspiera pracę

\footnotetext{
${ }^{9}$ DESI - Polska awansuje, ale znajduje się w dolnej części rankingu. [Online:] https://www.gov.pl/ web/cyfryzacja/desi-polska-awansuje-ale-wciaz-w-tyle. Dostęp: 03.10.2018.

10 [Online:] https://antyweb.pl/polskie-szkoly-dostep-do-internetu/. Dostęp: 03.10.2018, W roku 2017 minister ds. cyfryzacji Anna Streżyńska obiecywała, że sytuacja ma się całkowicie zmienić do 2020 roku, kiedy to we wszystkich polskich szkołach ma zastać zapewniony szybki Internet. Jej następca jeszcze się na ten temat nie wypowiedział.
} 
dydaktyczną, umożliwiając choćby przesyłanie zadań, a nawet wspólną (tzw. synchroniczną) pracę uczniów z nauczycielem.

Przechodząc do wad, należy podkreślić wielokrotnie opisywany przez naukowców zakłócenia w koncentracji uwagi stwierdzone u uczniów korzystających z przeglądarek internetowych. Zawsze istnieje ryzyko, że zanim uruchomi się właściwą stronę, „przypadkowo” uwaga zostanie odciągnięta przez ciekawą informację na innej stronie, reklamę lub inną aplikację zainstalowaną na komputerze ucznia (np. komunikator lub powiadomienie o przyjściu e-maila) ${ }^{11}$. Pisząc o mankamentach korzystania z zasobów sieciowych, trudno nie odnieść się do danych dotyczących poziomu komputeryzacji szkół i zapytać: jakiego procentu szkół taka wspólna i bezkonfliktowa praca w sieci dotyczy, skoro tylko niewielki odsetek ma dostęp do Internetu o wysokiej prędkości? Najczęściej więc korzystanie z sieci ogranicza się w przypadku nauczyciela do wypełniania elektronicznego dziennika, komunikacji z uczniami i rodzicami, a w wymiarze dydaktycznym do wyszukiwania informacji i najprostszego przeglądania zawartości Internetu.

Uwagi powyższe potwierdzają wyniki opracowania Polska szkoła w dobie cyfryzacji. Diagnoza 2017 przygotowanego przez zespół badawczy z Wydziału Pedagogicznego Uniwersytetu Warszawskiego oraz PCG Edukacja pod redakcją Marleny Plebańskiej ${ }^{12}$. Według autorów raportu technologie cyfrowe stosowane są w około połowie polskich szkół, zaś blisko 50\% ankietowanych zadeklarowało, iż w ich szkole nie są stosowane żadne cyfrowe technologie. Zdecydowana większość ankietowanych, bo aż 75\%, może korzystać ze sprzętu szkolnego tylko na lekcjach, jednak nadal 20\% przynosi na lekcje swój własny (prywatny) sprzęt i wykorzystuje go w czasie zajęć. Tylko 4\% ankietowanych ma możliwość korzystania ze sprzętu szkolnego także w domu. Większość uczniów w szkole korzysta z własnego dostępu do Internetu (52\%), 27\% uczniów nie ma wcale w placówkach dostępu do Internetu, 23\% korzysta w szkole z dobrej jakości sieci bezprzewodowej. Zdecydowana mniejszość - 8\% - ma możliwość korzystania w szkole z najwydajniejszej sieci przewodowej ${ }^{13}$.

Odnosząc się do tych danych, można stwierdzić, że o ile technologie cyfrowe powszechnie zaistniały w życiu codziennym (zwłaszcza dzieci i młodzieży), doprowadziły do modernizacji wielu gałęzi przemysłu, usług, a nawet administracji, przemodelowały społeczną przestrzeń komunikacyjną, to

\footnotetext{
${ }^{11}$ Wyczerpująco o efekcie multitaskingu (wielozadaniowości) polegającym na przeskakiwaniu z jednej informacji na drugą (która w skrajnych przypadkach przeradza się nerwicę) pisali: Holtkamp J., 2011, Co ogłupia nasze dzieci. Nowe media jako wyzwanie dla rodziców, Kraków; Small G., Vorgan G., 2011, iMózg. Jak przetrwać technologiczna przemianę współczesnej umysłowości, Poznań; Spitzer M., 2016, Cyberchoroby. Jak cyfrowe życie rujnuje nasze zdrowie, Słupsk; Spitzer M., 2013, Cyfrowa demencja. W jaki sposób pozbawiamy rozumu siebie i swoje dzieci, Słupsk.

12 Badanie, na podstawie którego powstał raport Polska szkoła $w$ dobie cyfryzacji. Diagnoza 2017, zostało przeprowadzone w 2017 roku w grupie 100129 respondentów: uczniów, rodziców, nauczycieli i kadry zarządzającej.

${ }^{13}$ Polska szkoła $w$ dobie cyfryzacji. Diagnoza 2017. Raport opracowany przez zespół badawczy Wydziału Pedagogicznego Uniwersytetu Warszawskiego oraz PCG Edukacja, 2017, Plebańska M. (red), Warszawa, s. 10. [Online:] https://www.cyfrowobezpieczni.pl/uploads/filemanager/raporty/ RAPORT CYFRYZCJA_SZKOL_2017.pdf. Dostęp: 03.10.2018.
} 
ich obecność i funkcja w szkołach albo jest symboliczna (w salach komputerowych znajduje się przestarzały sprzęt), albo niewystarczająca (np. w szkole jest ściśle reglamentowany dostęp do jedynej dobrze wyposażonej pracowni komputerowej lub do jedynej tablicy multimedialnej), albo niewykorzystana (nauczyciele nie mogą lub nie umieją korzystać z możliwości, jakie dają nowoczesne narzędzia cyfrowe).

Analiza podstaw programowych kształcenia ogólnego dla różnych typów szkół od tej z roku 2008 (zmienionej w roku 2012) po najnowsze z roku 2017 i 2018 r. nie pozostawia wątpliwości, że technologie cyfrowe były i są zauważane, i w mniejszym lub większym zakresie są wprowadzane do nauczania przedmiotowego. Istotna jest jednak analiza konkretnych zagadnień, a szczególnie dostrzegalna wizja docelowych kompetencji i umiejętności cyfrowych, które mają zostać wykształcone przez korzystanie z technologii. W tym kontekście ważną sprawą jest fakt, że zgodnie programami nauczania wszyscy uczniowie uczestniczą w zajęciach informatyki (dla edukacji wczesnoszkolnej są to zajęcia komputerowe). Według stosownych podstaw programowych nauczyciele tego przedmiotu zobligowani są do wprowadzenia zarówno podstaw informatyki (w zakresie poznawania urządzeń cyfrowych) i programowania, oprogramowania (w tym ćwiczeń rachunkowych w aplikacji Excel i edycji tekstu w programie Word), metod komunikowania, zasad bezpiecznego korzystania zarówno z urządzeń, jak też społecznego funkcjonowania w sieci.

Wyraźnie da się zauważyć, że w edukacji dostrzeżono istotną rolę Internetu jako istotnego medium współczesnego świata, ale także jako zjawiska społecznego. W Podstawie programowej $z$ informatyki dla klas VIIVIII $^{14}$ ogłoszonej w roku 2017 czytamy, że uczeń:

Korzystając z aplikacji komputerowych, przygotowuje dokumenty i prezentacje, także $\mathrm{w}$ chmurze, na pożytek rozwiązywanych problemów i własnych prac z różnych dziedzin (przedmiotów), dostosowuje format i wygląd opracowań do ich treści i przeznaczenia, wykazując się przy tym umiejętnościami:

a) tworzenia estetycznych kompozycji graficznych: tworzy kolaże, wykonuje zdjęcia i poddaje je obróbce zgodnie z przeznaczeniem, nagrywa krótkie filmy oraz poddaje je podstawowej obróbce cyfrowej,

b) tworzenia różnych dokumentów: formatuje i łączy teksty, wstawia symbole, obrazy, tabele, korzysta z szablonów dokumentów, dłuższe dokumenty dzieli na strony,

c) rozwiązywania zadań rachunkowych z programu nauczania z różnych przedmiotów w zakresie szkoły podstawowej, z codziennego życia oraz implementacji wybranych algorytmów w arkuszu kalkulacyjnym: umieszcza dane w tabeli arkusza kalkulacyjnego, posługuje się podstawowymi funkcjami, stosuje adresowanie względne, bezwzględne i mieszane, przedstawia dane w postaci różnego typu wykresów, porządkuje i filtruje dane,

${ }^{14}$ Podstawa programowa z informatyki - szkoła podstawowa. [Online:] https://men.gov.pl/ wp-content/uploads/2016/11/podstawa-programowa-z-informatyki-szkola-podstawowa.pdf. Dostęp: 03.10.2018. 
d) tworzenia prezentacji multimedialnej wykorzystując tekst, grafikę, animację, dźwięk i film, stosuje hiperłącza,

e) tworzenia prostej strony internetowej zawierającej: tekst, grafikę, hiperłącza, stosuje przy tym podstawowe polecenia języka HTML;

4) zapisuje efekty swojej pracy w różnych formatach i przygotowuje wydruki;

5) wyszukuje w sieci informacje potrzebne do realizacji wykonywanego zadania, stosując złożone postaci zapytań i korzysta z zaawansowanych możliwości wyszukiwarek (Podstawa programowa z informatyki..., 2016, 8).

Zaprezentowane kompetencje i umiejętności brzmią imponująco. W tej samej podstawie znajdziemy więcej bardzo ciekawych propozycji - w tym postulat rozwijania wrażliwości cyfrowego odbiorcy i świadomego uczestnika społeczeństwa sieciowego (patrz część pt. Rozwijanie kompetencji społecznych). Warto jednak ponownie zestawić te zapisy z opisywanym wcześniej mizernym wyposażeniem sporej części szkół.

Takiej niespójności oczekiwań i efektów nauczania kompetencji informacyjno-komunikacyjnych (TiK) doświadczam każdego roku w trakcie prowadzonych od roku 2009 zajęć pt. Edukacja naukowo-informatyczna dla studentów pierwszego roku studiów licencjackich na kierunku filologia polska (a więc niedawnych maturzystów). Studenci pytani o zapamiętane przez nich zajęcia $\mathrm{z}$ informatyki na poprzednich etapach edukacji niezmiennie od dziesięciolecia reagują śmiechem, litanią skarg i negatywnych komentarzy dotyczących sposobu prowadzenia tych zajęć w szkołach. Również analiza umiejętności studentów, zwłaszcza w ramach praktycznych ćwiczeń z podstaw edycji tekstu lub tworzenia i zarządzania serwisami internetowymi, nie pozostawia wątpliwości, że ich edukacja w szkole w tym zakresie albo była nieskuteczna, albo jej w ogóle nie było (Wobalis 2016).

W przypadku pytań o sposoby wykorzystania technologii cyfrowych na lekcjach języka polskiego bardzo wymowną reakcją jest milczenie lub jednostkowe świadectwa o prezentowaniu obrazków, przeszukiwaniu stron lub ćwiczeniach dotyczących edycji tekstu. Warto ponownie zadać pytanie o korelacje uwarunkowań technologicznych (wyposażenie szkół) i organizacyjnych (odpowiednio przeszkolona kadra nauczycielska) z założeniami programowymi. Z punktu widzenia badacza, który od ponad dwudziestu lat obserwuje rozwój edukacji informatycznej w Polsce, sytuacja ta przywodzi na myśl romantyczne mierzenie sił na zamiary, nie zaś pozytywistyczną i przemyślaną pracę organiczną. W uzupełnieniu do tego niezbyt pozytywnego obrazu trzeba dodać, że uczniowie w szkole średniej, którzy wybrali profil humanistyczny, uczęszczają na zajęcia informatyki jedynie w pierwszej klasie, co również przekłada się na ich późniejsze kompetencje informatyczne.

Kolejną ważną kwestią jest programowa wizja powiązania nauczania polonistycznego z technologiami cyfrowymi, mediami i nowymi mediami. $\mathrm{W}$ podstawie programowej z roku 2008 zagadnienia te pojawiają się na lekcji języka polskiego dopiero w gimnazjum, jednakże uznać je można za 
liczne i jak na ówczesne czasy wystarczające. Już w komentarzu do tego dokumentu czytamy:

Współczesny uczeń żyje w świecie szeroko postrzeganych tekstów kultury, przede wszystkim istniejących $\mathrm{w}$ zapisie elektronicznym. Powinnością polonisty staje się więc nie tylko wprowadzenie go w rzeczywistość językową i świat literatury, lecz również dostarczenie mu zróżnicowanych narzędzi, które umożliwią sprawne poruszanie się w tej skomplikowanej rzeczywistości (Podstawa programowa $z$ komentarzami. Tom 2. Język polski w szkole podstawowej, gimnazjum i liceum, 2008, 56).

Do najważniejszych umiejętności zdobywanych przez ucznia w trakcie kształcenia ogólnego na III (aktualnie „wygaszanym”) i IV etapie edukacyjnym zaliczono m.in.:

umiejętność sprawnego posługiwania się nowoczesnymi technologiami informacyjno-komunikacyjnymi (Podstawa programowa ..., 2008, 15).

\section{Za zadanie szkoły uznano natomiast}

przygotowanie uczniów do życia w społeczeństwie informacyjnym (Podstawa programowa ..., 2008, 16),

\section{zaś nauczycieli zobowiązano do stwarzania uczniom warunków}

do nabywania umiejętności wyszukiwania, porządkowania i wykorzystywania informacji z różnych źródeł, z zastosowaniem technologii informacyjno-komunikacyjnych (Podstawa programowa ..., 2008, 16).

\section{Ponadto}

nauczyciel powinien poświęcić dużo uwagi edukacji medialnej, czyli wychowaniu uczniów do właściwego odbioru i wykorzystania mediów (Podstawa programowa ..., 2008, 16).

Wymagania szczegółowe dla gimnazjum i liceum związane z poruszanym zagadnieniem prezentują się $\mathrm{w}$ przywołanym dokumencie następująco ${ }^{15}$ :

\begin{tabular}{|c|c|}
\hline Gimnazjum & Liceum \\
\hline $\begin{array}{l}\text { W zakresie samokształcenia i docierania do } \\
\text { informacji uczeń: } \\
\text { - samodzielnie dociera do informacji - } \\
\text { w książkach, prasie, mediach elektro- } \\
\text { nicznych, korzysta ze słownika: języka } \\
\text { polskiego, poprawnej polszczyzny, } \\
\text { frazeologicznego, wyrazów obcych, } \\
\text { synonimów i antonimów oraz szkol- } \\
\text { nego słownika terminów literackich - } \\
\text { w formie książkowej i elektronicznej } \\
(\mathrm{s} .36)^{16} \text {. }\end{array}$ & $\begin{array}{l}\text { Uczeń porównuje tekst linearny i hipertekst } \\
\text { (s. 43). } \\
\text { - } \text { szuka literatury przydatnej do opraco- } \\
\text { wania różnych zagadnień (...), } \\
\text { - korzysta z tradycyjnego księgozbioru, } \\
\text { jak i zapisów multimedialnych i elek- } \\
\text { tronicznych, w tym Internetu (s. 44). }\end{array}$ \\
\hline
\end{tabular}

15 Wszystkie cytaty: Podstawa programowa z komentarzami Tom 2. Język polski w szkole podstawowej, gimnazjum i liceum..., 2008, s. 36-45.

${ }^{16}$ Niepokój wzbudza stwierdzenie „samodzielnie”, do którego wielokrotnie odnoszą się ankietowani przeze mnie studenci I roku filologii polskiej, wskazując, że kompetencje cyfrowe zostały przez nich nabyte głównie właśnie samodzielnie i poza szkołą. 


\begin{tabular}{|c|c|}
\hline $\begin{array}{l}\text { W zakresie mówienia i pisania uczeń: } \\
\text { - dokonuje starannej redakcji tek- } \\
\text { stu napisanego ręcznie i na kompu- } \\
\text { terze (umiejętnie formatuje tekst, } \\
\text { dobiera rodzaj czcionki wg rozmiaru } \\
\text { i kształtu, stosuje właściwe odstępy, } \\
\text { wyznacza marginesy i justuje tekst, } \\
\text { dokonuje jego korekty), } \\
\text { - przestrzega zasad etyki mowy w róż- } \\
\text { nych sytuacjach komunikacyjnych, } \\
\text { m.in. zna konsekwencje stosowania } \\
\text { form charakterystycznych dla elek- } \\
\text { tronicznych środków przekazywania } \\
\text { informacji, takich jak SMS, e-mail, } \\
\text { czat, blog (s. 38), } \\
\text { świadomie, odpowiedzialnie, selek- } \\
\text { tywnie korzysta (jako odbiorca } \\
\text { i nadawca) z elektronicznych środ- } \\
\text { ków przekazywania informacji, w tym } \\
\text { z Internetu (s. 39). }\end{array}$ & $\begin{array}{l}\text { Uczeń tworzy przedmiotowe bazy danych. } \\
\text { - } \text { sporządza opis bibliograficzny zapi- } \\
\text { sów elektronicznych (s. 45). } \\
\text { - } \text { dostrzega współczesne zmiany } \\
\text { modelu komunikacji językowej, róż- } \\
\text { nice miedzy tradycyjną komunikacją } \\
\text { ustną lub pisaną a komunikacją przez } \\
\text { Internet (s. } 45)^{17} \text {. }\end{array}$ \\
\hline
\end{tabular}

W przypadku Podstawy programowej z 14 lutego 2017 roku dla szkoły podstawowej autorzy konstatują w preambule:

Szkoła ma stwarzać uczniom warunki do nabywania wiedzy i umiejętności potrzebnych do rozwiązywania problemów z wykorzystaniem metod i technik wywodzących się z informatyki, w tym logicznego i algorytmicznego myślenia, programowania, posługiwania się aplikacjami komputerowymi, wyszukiwania i wykorzystywania informacji z różnych źródeł, posługiwania się komputerem i podstawowymi urządzeniami cyfrowymi oraz stosowania tych umiejętności na zajęciach z różnych przedmiotów m.in. do pracy nad tekstem, wykonywania obliczeń, przetwarzania informacji i jej prezentacji w różnych postaciach (Podstawa programowa kształcenia ogólnego z komentarzem, 2017, 7).

Zagadnienia związane z nową rzeczywistością komunikacyjną sprawiają wrażenie, że zostały przeniesione w sporej części z zapisów opisujących umiejętności w Podstawie programowej z roku 2008 dla gimnazjum. W zakresie samokształcenia podkreśla się wagę efektywnego wykorzystywania technologii cyfrowych do poszukiwania, selekcjonowania i wykorzystywania informacji. W zakresie odbioru tekstów kultury uczeń nie tylko ma rozróżniać różne media, ale w dodatku dokonywać odczytania tekstów przez przekład intersemiotyczny (Podstawa programowa kształcenia ogólnego z komentarzem, 2017, 13). W zakresie mówienia i pisania uczeń:

rozróżnia współczesne formy komunikatów (np. e-mail, SMS) i odpowiednio się nimi posługuje, zachowując zasady etykiety językowej (Podstawa programowa..., 2017, 15).

${ }^{17}$ Warto także zauważyć, że w omawianej podstawie programowej z roku 2008 już od II etapu kształcenia (klasy IV-VI) odnajdziemy liczne odniesienia do kultury popularnej i mediów audiowizualnych. 


\section{W zakresie samokształcenia:}

zna i stosuje zasady korzystania z zasobów bibliotecznych (np. w bibliotekach szkolnych oraz on-line) (Podstawa programowa..., 2017, 14)

\section{oraz}

rozwija umiejętności efektywnego posługiwania się technologią informacyjną oraz zasobami internetowymi i wykorzystuje te umiejętności do prezentowania własnych zainteresowań (Podstawa programowa..., 2017, 16).

Dużym zaskoczeniem jest, że w najnowszej podstawie programowej dla uczniów z klas VII-VIII (zgodnie z wieloma badaniami wskazuje się, że jest to grupa najsilniej zanurzona w przestrzeni cyfrowej) w żadnej z ważnych części związanych z odbiorem tekstu kultury, komunikacji językowej, tworzenia wypowiedzi ( $w$ tym mówienia i pisania) nie odnajdziemy odniesień do nowych mediów, technologii cyfrowych, Internetu itd. Jedynie w ramach samokształcenia uczeń:

uczestniczy w projektach edukacyjnych (np. tworzy różnorodne prezentacje, projekty wystaw, realizuje krótkie filmy z wykorzystaniem technologii multimedialnych) (Podstawa programowa..., 2017, 20).

Analiza aktualnych dokumentów przygotowanych przez Ministerstwo Edukacji Narodowej wskazuje na odwrócenie się autorów Podstawy programowej dla szkoły podstawowej od rzeczywistości cyfrowej i skupienie się wyłącznie na kształceniu literackim oraz tradycyjnym postrzeganiu komunikacji. Oznacza to celowe i wyraźne wycofanie się z obecnej w podstawie z roku 2008 otwartości wobec nowych zjawisk komunikacyjnych i sytuuje kształcenie polonistyczne w rzeczywistości końca XX wieku, czyli w erze sprzed komputeryzacji, Internetu i kultury konwergencji. Co jednak najbardziej zaskakujące, zapisy szczegółowe z roku 2017 stoją w całkowitej sprzeczności z wyrażonymi w preambule ideami.

W ogłoszonej w styczniu 2018 Podstawie programowej kształcenia ogólnego dla liceum ogólnokształcacego, technikum oraz branżowej szkoły II stopnia ${ }^{18} \mathrm{w}$ zakresie przewidzianym dla języka polskiego tendencja ta jest utrzymana. Warto zauważyć, że język jest w tym przypadku postrzegany przede wszystkim jako:

podstawa rozumienia tekstów, wypowiadania się ustnie i pisemnie w różnych formach, umiejętnego argumentowania swoich sądów i przekonań. Kompetencje językowe warunkowane znajomością gramatyki języka, jego zasobu leksykalnego i stylistyki, stanowią podstawę do rozwijania kompetencji komunikacyjnych. Świadomość sytuacji, w której odbywa się komunikacja, świadomość reguł, których wymaga komunikowanie się z otaczającym światem, nie tylko reguł gramatycznych, także zasad kultury języka, to podstawowa dla człowieka umiejętność we współczesnym świecie. Dopełnieniem kompetencji komunikacyjnej jest znajomość

${ }^{18}$ Rozporzadzenie Ministra Edukacji Narodowej z dnia 30 stycznia 2018 r. w sprawie podstawy programowej kształcenia ogólnego dla liceum ogólnokształcącego, technikum oraz branżowej szkoły II stopnia. 
i stosowanie zasad ortografii i interpunkcji. Rozwijanie kompetencji językowych i komunikacyjnych ucznia warunkuje zatem kształcenie odbioru tekstów oraz ich tworzenie (Podstawa programowa kształcenia ogólnego dla liceum, 2018).

W wytycznych dotyczących kształcenia językowego, jak i w części dotyczącej tworzenia wypowiedzi, nie odnajdziemy żadnych odwołań do kompetencji cyfrowych, choć sporo miejsca poświęcono dbałości o estetykę tekstu, redakcję i korektę, które w dzisiejszych czasach wykonuje się zazwyczaj w komputerze ${ }^{19}$. Technologie informacyjne pojawiają się wyłącznie w ramach samokształcenia jako narzędzia służące poszukiwaniu, porządkowaniu i wykorzystywaniu pozyskanych informacji. Odnajdziemy tam wykaz umiejętności - m.in. tworzenie bazy danych, korzystanie ze źródeł elektronicznych (np. słowników on-line), wykorzystywanie multimediów (bez podania jakich, do czego i jak...), umiejętność wyboru źródeł internetowych, krytycznej analizy multimediów i hipertekstu (w tym określanie ich funkcji w komunikacji). Mimo że większość wprowadzanych w nowej podstawie programowej zapisów pochodzi z poprzedniej wersji tego dokumentu, to pierwsze wrażenie jest bardzo pozytywne. Jednakże skrótowość i hasłowość zapisów, brak ich rozwinięcia i wyraźnego wskazania funkcji dydaktycznej, brak odwołań do tradycji i współczesności kształcenia polonistycznego (kontekstowość, intertekstualność, obecność mediów w nauczaniu, multimedia jako przekaz artystyczny itd.) budzi obawy. Niepokój potęguje usytuowanie tych zagadnień wyłącznie w kategorii dotyczącej samokształcenia, sugerujące, że XXI-wieczne szkolne nauczanie polonistyczne dystansuje się od nowych zjawisk społeczno-komunikacyjno-kulturowych.

Mimo opisanych zastrzeżeń lektura wszystkich podstaw programowych potwierdza, że technologie informacyjne, multimedia i Internet stały się istotną częścią kształcenia polonistycznego. Problemem jak zwykle pozostaje sposób/pomysł efektywnego realizowania tych zapisów w praktyce szkolnej. Ich istotną słabością jest bowiem formułowanie wymagań i efektów bardzo ogólnie i raczej w niewielkim stopniu uwzględniające swoistość przedmiotu język polski (można by je wpisać do każdego innego przedmiotu). Ważnym i dostrzegalnym w obu podstawach błędem jest postrzeganie technologii informatycznych wyłącznie $\mathrm{w}$ charakterze operacyjnym (jako pobocznych i dodatkowych narzędzi pracy). Zapisy szczegółowe skupiają się na dość prostych umiejętnościach technicznych dotyczących szeroko rozumianej pracy na komputerze, trudno natomiast powiedzieć, jak stymulują kształtowanie postaw kreatywnych i twórczych. W rzeczywistości, w której na co dzień dzieci i nastolatkowie korzystają z technologii cyfrowych wiele godzin, może się to okazać niewybaczalnym błędem zaniechania.

Warto również spojrzeć na najpopularniejsze metody pracy z technologiami cyfrowymi w szkołach. Wśród licznej grupy nauczycieli odnajdziemy

19 Przypomnę, że kwestie dotyczące tworzenia i redakcji tekstu w specjalistycznym programie komputerowym znajdują się w podstawie programowej do informatyki. 
entuzjastów ${ }^{20}$, jednak większość stara się oswajać nowoczesne narzędzia „po swojemu” lub stosować je tak, jak nauczyli się na studiach czy w trakcie szkoleń komputerowych. Dobrym przykładem takiego neutralnego podejścia są wyniki cytowanych wcześniej badań Polska szkoła $w$ dobie cyfryzacji. Diagnoza 2017:

1. Technologie cyfrowe stosowane są w około połowie polskich szkół. Blisko 50\% ankietowanych zadeklarowało, iż $\mathrm{w}$ ich szkole nie są stosowane żadne cyfrowe technologie.

2. Typowa lekcja przy wykorzystaniu cyfrowych technologii edukacyjnych przebiega na ogół metodą frontalną, zbiorową, kiedy to nauczyciel użytkuje sprzęt, a uczniowie są biernymi odbiorcami przekazywanych treści. Nauczyciele najczęściej korzystają z prezentacji multimedialnych (42\%) oraz tablic interaktywnych (27\% głosów). Na zajęciach szkolnych zdecydowanie najrzadziej wykorzystuje się eksperyment, gry dydaktyczne etc.

3. W większości szkół jako najczęściej użytkowany sprzęt na zajęciach wskazuje komputer. Na drugim miejscu znalazła się tablica multimedialna, na trzecim smartfon. Z tabletu korzysta tylko $2 \%$ respondentów. Interfejsy pomiarowe, klocki do nauki programowania czy roboty prawie w ogóle nie są wykorzystywane w szkołach (korzysta z nich tylko około $1 \%$ respondentów).

4. Cyfrowe zasoby edukacyjne stosowane są w około połowie polskich szkół, w większości są to prezentacje multimedialne, rzadziej materiały multimedialne, np. filmy, animacje, materiały graficzne, np. ilustracje, tabele. Następne w kolejności pod względem częstotliwości wykorzystywania są podręczniki cyfrowe oraz materiały audio i materiały interaktywne, np. gry, quizy. Najmniej respondentów korzysta z aplikacji mobilnych i e-booków.

5. Zdecydowana większość ankietowanych (ok. 80\%) uważała, że zastosowanie cyfrowych technologii edukacyjnych na zajęciach zwiększa zarówno efektywność, jak i atrakcyjność lekcji.

6. Blisko $80 \%$ badanych uważa, że zastosowanie cyfrowych technologii edukacyjnych na zajęciach zwiększa zaangażowanie uczniów.

7. W opinii badanych cyfrowe technologie edukacyjne stanowią przede wszystkim uzupełnienie zajęć tradycyjnych.

9. Zajęcia z wykorzystaniem TIK mają zwykle tradycyjną strukturę, organizację i przebieg. Dominują metody podające (ok. $70 \%$ ), co wskazuje na transmisyjny charakter edukacji (Plebańska 2017, 10-11).

Przedstawione wyniki owej diagnozy trudno pozostawić bez komentarza. Jeśli główną metodą nauczania $\mathrm{z}$ wykorzystaniem technologii jest metoda podająca z tradycyjną strukturą, organizacją, przebiegiem i transmisyjnym charakterem edukacji (p. 9), dominuje bierny odbiór przekazu przez ucznia (p. 2), urządzenia traktowane są przeważnie jako uzupełnienie zajęć tradycyjnych (p. 7), a najczęściej wykorzystywanym przez ucznia urządzeniem jest zwykły komputer (p. 3), to trudno zrozumieć, na czym polegać ma zwiększenie atrakcyjności, efektywności (p. 5-6) tak realizowanych lekcji?

${ }^{20}$ Zob. artykuł „Oswajanie” nowych technologii na lekcjach języka polskiego autorstwa Sabiny Walerii Świtały w 7 numerze pisma „Polonistyka. Innowacje” z roku 2017. 
Warto również spojrzeć na to, jak w cytowanych badaniach zespołu Marleny Plebańskiej technologie odbierane są przez uczniów:

Uczniowie popierają zastosowanie technologii cyfrowych w edukacji. Cyfrowe technologie edukacyjne zdaniem młodzieży stanowią przede wszystkim uzupełnienie zajęć tradycyjnych. Takiej odpowiedzi udzieliło 38\% respondentów. Dla podobnej liczby ankietowanych (36\%) są one sposobem na wspieranie przebiegu typowych lekcji. Ponad $1 / 4$ ankietowanych preferuje nauczanie i uczenie się poprzez TIK, a nie tylko z jego wykorzystaniem. Co czwarty ankietowany uważa, że nowoczesne technologie zastępują lub wypierają zajęcia standardowe.

$\mathrm{Na}$ pytanie „Opisz najciekawszą lekcję z wykorzystaniem cyfrowych technologii edukacyjnych, w jakiej ostatnio uczestniczyłeś", wiele osób w ogóle nie odpowiedziało. Inni odpowiadali wprost, że nie pamiętają takiej lekcji. W szkole, w której się uczą, nie wykorzystuje się nowoczesnych technologii multimedialnych. W większości wykorzystywanie nowoczesnych technologii na lekcjach sprowadzało się do realizacji zasady poglądowości, możliwości przedstawiania rzeczy i zjawisk niedostępnych bezpośredniemu poznaniu. Uczniowie w takich sytuacjach raczej biernie przyswajali informacje przedstawiane w bardziej obrazowy sposób (wyświetlane na komputerze, rzutniku lub tablicy interaktywnej). Dużo rzadziej nowoczesne technologie służyły samodzielnemu zdobywaniu wiedzy przez uczniów, jej konstruowaniu. Sporadycznie pojawiały się wypowiedzi dotyczące możliwości kodowania, programowania przez uczniów, eksponowane w nowej podstawie programowej (Plebańska 2017, 11).

Przywołane obserwacje zawierają sporo zaskakujących niezgodności czy paradoksów i dowodów na myślenie życzeniowe. Na przykład dla $25 \%$ badanych nowoczesne technologie wypierają tradycyjne nauczanie, jednak większość badanych nie potrafiła wymienić przykładu ciekawej lekcji z wykorzystaniem technologii. Uwagi uczniów (a w części również i nauczycieli) mogą być także potwierdzeniem stereotypowego (albo stymulowanego przez producentów urządzeń) przeświadczenia o „oczywistej” przydatności i efektywności narzędzi technologicznych. Być może jest więc tak, że neutralność (czasami niechęć) części nauczycieli i uczniów wobec technologii istnieć będzie, dopóki będą one mechaniczne, cyfrowe, a tym samym sztuczne. Jako takie są bowiem ciągle obce zmysłowemu doznaniu rzeczywistości ${ }^{21}$.

\section{Zakończenie}

Już w latach 80. XX wieku amerykański uczony i entuzjasta technologii w nauczaniu Larry Cuban w książce Teachers and Machines: The Classroom Use of Technology Since 1920 zauważył, że etapy wprowadzania technologii do edukacji (poczynając od radia) realizowane są w powtarzających się cyklach stymulowanych głównie przez przedstawicieli wytwórców urządzeń:

${ }^{21}$ Przykładem niech będzie różnica między: a) żywym drzewem oglądanym (doświadczanym) w parku lub lesie, b) modelem drzewa w skali 1:1 obserwowanym w muzeum, c) dwuwymiarowym obrazem drzewa prezentowanym z projektora multimedialnego na szkolnej ścianie. 
Każdy cykl rozpoczyna się od wielkich obietnic naukowców i wynalazców nowych technologii. W szkołach akceptacja nowych narzędzi jest raczej niewielka, w związku z czym trudno mówić o prawdziwym postępie naukowym. To z kolei prowadzi często do tych samych spekulacji w kwestii brakujących środków finansowych, oporu kadry nauczycielskiej albo opieszałości zbiurokratyzowanego systemu szkolnictwa. Jednak nikt nie kwestionuje tego, co wygłaszają prekursorzy nowych technologii, a że obiecywanych efektów postępu wciąż nie widać, ostatecznie odpowiedzialnością za niepowodzenie obarcza się maszyny. Wkrótce potem szkołom sprzedaje się najnowszą generację sprzętu technicznego i tak rozpoczyna się kolejny intratny cykl tego procesu (Caban, 1986) ${ }^{22}$.

W roku 1998 sam byłem entuzjastą multimediów i podręczników multimedialnych, na które zapotrzebowanie - jak pisałem wcześniej - skończyło się w sposób naturalny w pierwszym dziesięcioleciu XXI wieku. Niedługo potem pojawiła się w Polsce rewolucja internetowa, a chwilę później nastąpił etap powszechnej fascynacji mediami społecznościowymi (warto jednak zauważyć, że Facebook z roku na rok odnotowuje coraz większy ubytek użytkowników - szczególnie wśród osób młodych) ${ }^{23}$. Po nim nastąpił trwający do dzisiaj etap mody na urządzenia mobilne (pojawił się nawet m-learning), w powszechnym użyciu są dotykowe ekrany interaktywne ${ }^{24}$, za chwilę będą to również okulary VR oraz interfejsy ściślej współgrające z ciałem (bezpośrednia stymulacja zmysłów, a później bezpośrednia stymulacja neuronów ${ }^{25}$ ). Uważam więc, że do czasu upowszechnienia się technologii integralnie powiązanej ze zmysłami i w sposób rzeczywisty symulujących rzeczywistość (np. na realistyczny spacer po muzeum lub obserwacje zjawisk naturalnych, symulacje doznawania kształtu, ciężaru, smaku, zapachu) czeka nas ciągła niekoherentna symbioza technologii i edukacji. Integracja technologii z człowiekiem na taką skalę nazwana została przez Vernora Vinge „technologiczną osobliwością”, a współcześnie przez Roya Kurzweila wielką osobliwością ${ }^{26}$, który prognozuje jej zaistnienie w drugiej połowie XXI wieku.

${ }^{22}$ Cytat za: Spitzer M., 2013, Cyfrowa demencja. W jaki sposób pozbawiamy rozumu siebie i swoje dzieci, Słupsk, s. 81.

${ }^{23}$ Facebook traci młodych użytkowników - 2,8 mln w USA w 2017 roku. „To masowe medium dla starych ludzi", 2018. [Online:]: https://www.wirtualnemedia.pl/artykul/facebook-traci-mlodych-uzytkownikow-2-8-miliona-w-2017-roku-to-masowe-medium-dla-starych-ludzi. Dostęp: 03.10.2018.

${ }^{24}$ Manfred Spitzer w Cyfrowej demencji wyraził pogląd, że nie ma niczego bardziej powierzchownego w edukacji niż przesuwanie palcem po płaskim ekranie (monitora, tablicy multimedialnej, tabletu itp.) elementu graficznego z jednego miejsca ekranu w drugie (Spitzer 2013, 72).

${ }^{25}$ Huang H., Delikanli S., Zeng H., Ferkey D.M., Pralle A., 2010, Remote control of ion channels and neurons through magnetic-field heating of nanoparticles, „Nature Nanotechnology”, volume 5, ss. 602-606. [Online:] https://www.nature.com/articles/nnano.2010.125. Dostęp: 03.10.2018.

${ }^{26}$ Osobliwością technologiczną (lub „wielką osobliwością) nazywa się taki hipotetyczny moment w rozwoju cywilizacji, w którym postęp techniczny stanie się tak szybki, że wszelkie ludzkie przewidywania przyszłości staną się nieaktualne lub obarczone będą zbyt dużym ryzykiem błędu. Najważniejszym wydarzeniem, mającym do tego doprowadzić, będzie - wg m.in. Kurzweila - stworzenie sztucznych inteligencji znacznie przewyższających intelektualne możliwości ludzi. Na dalszym etapie sztuczne inteligencje mogłyby opracowywać jeszcze wydajniejsze sztuczne inteligencje, wywołując lawinową zmianę w rozwoju cywilizacji. Vinge V., 1993, The Coming Technological Singularity: How to Survive in the Post-Human Era. [Online:] https://edoras.sdsu.edu/ vinge/misc/singularity. html. Dostęp: 03.10.2018, Kurzweil R., 2016, Nadchodzi osobliwość, Kiedy człowiek przekroczy granice biologii, Warszawa. 
Jakaż jest więc najbliższa przyszłość relacji technologii z edukacją? Niezależnie od futurystycznych przewidywań, życzeń i lęków wiarygodną odpowiedź poznamy być może dopiero za kolejnych 20 lat - w roku 2038.

\section{Bibliografia:}

Cuban Larry, 1986, Teachers and Machines: The Classroom Use of Technology Since 1920, Teachers College Press, New York, London.

Filiciak Mirosław, 2013, Media, wersja beta. Film i telewizja w czasach gier komputerowych i Internetu, Gdańsk

Filipiak Marian, 2003, Homo communicans. Wprowadzenie do teorii masowego komunikowania, Lublin, s. 91-94.

Goban-Klas Tomasz, 1999, Media i komunikowanie masowe, Teorie i analizy prasy, radia, telewizji i internetu, Warszawa.

Holtkamp Jurgen, 2011, Co ogłupia nasze dzieci. Nowe media jako wyzwanie dla rodziców, Kraków.

Huang Heng, Delikanli Savas, Zeng Hao, Ferkey Denise M., Pralle Arnd, 2010, Remote control of ion channels and neurons through magnetic-field heating of nanoparticles, „Nature Nanotechnology” volume 5, ss. 602-606. [Online:] https://www.nature.com/articles/nnano.2010.125. Dostęp: 03.10.2018.

Jenkins Henry, 2007, Kultura konwergencji. Zderzenie starych i nowych mediów, Warszawa.

Kellner David, 2009, Media Industries, Political Economy, and Media/Cultural Studies, w: Media Industries. History, Theory and Method, Holt J., Perren A., (red.) Chichester: Wiley-Blackwell, s. 103 lub [Online:] https://pages.gseis. ucla.edu/faculty/kellner/essays/2009_Kellner blackwell_Chp7.pdf, s. 30-31, Dostęp: 03.09.2018.

Kurzweil Roy, 2016, Nadchodzi osobliwość. Kiedy człowiek przekroczy granice biologii, Warszawa.

Levinson Paul, 2010, Nowe nowe media, Kraków.

Manovich Lev, 2012, Język nowych mediów, Warszawa.

Moles Abraham, 1967, Sociodynamique de la culture, Paris.

Podstawa programowa kształcenia ogólnego z komentarzem, 2017, [Online:], https://www.ore.edu.pl/wp-content/uploads/2018/03/podstawa-programowaksztalcenia-ogolnego-z-komentarzem.-szkola-podstawowa-jezyk-polski.pdf.

Podstawa programowa z informatyki - szkoła podstawowa [Online:] https://men. gov.pl/wp-content/uploads/2016/11/podstawa-programowa-z-informatykiszkola-podstawowa.pdf. Dostęp: 03.10.2018.

Polska szkoła $w$ dobie cyfryzacji. Diagnoza 2017. Raport opracowany przez zespół badawczy Wydziału Pedagogicznego Uniwersytetu Warszawskiego oraz PCG Edukacja, 2017, Plebańska M. (red.), Warszawa, s. 10. [Online:] https://www.cyfrowobezpieczni.pl/uploads/filemanager/raporty// RAPORT_CYFRYZCJA_SZKOL_2017.pdf. Dostęp: 03.10.2018.

Puppel Stanisław, 2012, The human communication orders and the principle of natural language sustainability, „Oikeios Logos”, nr 9, s. 9-10.

Polonistyka. Innowacje

Numer 8, 2018 
Rozporzadzenie Ministra Edukacji Narodowej z dnia 23 grudnia 2008 w sprawie podstawy programowej wychowania przedszkolnego oraz kształcenia ogólnego w poszczególnych typach szkół (Dz. U. z 2009r. Nr 4, poz. 17).

Rozporzadzenie Ministra Edukacji Narodowej z dnia 30 stycznia 2018 r. w sprawie podstawy programowej kształcenia ogólnego dla liceum ogólnokształcacego, technikum oraz branżowej szkoły II stopnia. Załacznik nr 1. Podstawa programowa kształcenia ogólnego dla czteroletniego liceum ogólnokształcącego i pięcioletniego technikum. Dz.U. z 2017 r., poz. 59, 949 i 2203. [Online:] https://podstawaprogramowa.pl/Liceum-technikum/Jezykpolski. Dostęp: 03.10.2018.

Small Gary, Vorgan Gigi, 2011, iMózg. Jak przetrwać technologiczna przemianę współczesnej umysłowości, Poznań.

Spitzer Manfred, 2016, Cyberchoroby. Jak cyfrowe $\dot{z} y c i e$ rujnuje nasze zdrowie, Słupsk.

Spitzer Manfred, 2013, Cyfrowa demencja. W jaki sposób pozbawiamy rozumu siebie i swoje dzieci, Słupsk.

Świtała Sabina Waleria, 2017, „Oswajanie” nowych technologii na lekcjach języka polskiego, „Polonistyka. Innowacje” nr 7.

Vinge Vernor, 1993, The Coming Technological Singularity: How to Survive in the Post-Human Era. [Online:] https://edoras.sdsu.edu/ vinge/misc/ singularity.html. Dostęp: 03.10.2018

Wobalis Mirosław, 1998, Multimedia i edukacja, „Polonistyka” nr 3.

Wobalis Mirosław, 2008, Hybrydowy podręcznik multimedialny narzędziem czytania tekstów kultury, w: Teksty kultury w szkole, Myrdzik B., Tymianki L. (red.), Lublin, s. 377-386.

Wobalis Mirosław, 2016, Kompetencje informatyczne studentów filologii polskiej w latach 2010-2016, „Polonistyka. Innowacje”, nr 4.

Wysłouch Seweryna, 1998, Od redakcji. Szkołę trzeba wymyślić na nowo?, „Polonistyka” nr 3.

Zacher W. Lech, 2012, Refleksje o ideologii cyfrowego świata, w: Nasza cyfrowa przyszłość. Nadzieje - ryzyka - znaki zapytania, Warszawa, s. 115.

\section{O Autorze:}

Mirosław Wobalis - dr hab., adiunkt w Zakładzie Nauk Pomocniczych i Edytorstwa Instytutu Filologii Polskiej Uniwersytetu im. Adama Mickiewicza w Poznaniu. Autor i redaktor kilkunastu publikacji dotyczących relacji pomiędzy technologiami a edukacją, w tym m.in. książki Multimedia $w$ nauczaniu polonistycznym (2011), Nowe media i Technologie cyfrowe w kształceniu polonistów (2017). Twórca i administrator „Serwisu Edukacji Interaktywnej WFPiK UAM w Poznaniu". Wydziałowy koordynator ds. kształcenia na odległość. Krytyczny popularyzator nowych mediów i technologii cyfrowych w edukacji. 